\title{
Are metals in the muscle tissue of Mozambique tilapia a threat to human health? A case study of two impoundments in the Olifants River, Limpopo province, South Africa
}

\author{
Abraham Addo-Bediako, Sean M. Marr*, Antoinette Jooste and Wilmien J. Luus-Powell \\ Department of Biodiversity, University of Limpopo, P. Bag X1106, Sovenga 0727, South Africa
}

Received 8 November 2013; Accepted 28 April 2014

\begin{abstract}
Rural communities in South Africa are becoming increasingly reliant on freshwater fish to supplement their dietary protein requirement. Rising costs of other protein sources, increasing rural poverty and escalating rural populations are resulting in increasing consumption of fish from contaminated river systems. The Olifants River, Limpopo Basin, Eastern South Africa, has been systemically impaired and is now one of the most polluted rivers in South Africa. We measured the concentrations of metals in fish muscle tissue from two impoundments in the Olifants River (Flag Boshielo Dam and the Phalaborwa Barrage) and conducted a human health risk assessment following Heath et al., (2004) to investigate whether consumption of Oreochromis mossambicus from these impoundments posed a risk to the health of rural communities. Our results show that metals are accumulating in the muscle tissue of $O$. mossambicus even though the populations appear to be healthy. No patterns were observed in the ratios of the metals accumulated in the muscle tissue of $O$. mossambicus at each impoundment. The human health risk assessment identified that lead, antimony and chromium at Flag Boshielo Dam and lead at the Phalaborwa Barrage were above acceptable levels for the safe consumption based on a weekly $150 \mathrm{~g}$ fish meal. We conclude that consuming O. mossambicus from these impoundments could pose an unacceptable risk to the health of rural communities.
\end{abstract}

Key words: Bioaccumulation / metals / muscle tissue / Oreochromis mossambicus / human health risk

\section{Introduction}

Fish are a vital source of food for many of the world's people, especially low-income groups (Sayer and Cassman, 2013), as they are a rich source of protein, micronutrients and essential fatty acids (Beveridge et al., 2013), cheaper than other protein sources, and available from local lakes, rivers and impoundments. However, the consumption of fish could result in detrimental health impacts when harvested from contaminated inland waters. Globally, inland waters have been adversely impacted by constant increases in domestic, agricultural, mining and industrial water abstraction and the release of contaminants containing metals and pesticides (Vörösmarty et al., 2010). Although most metals naturally occur in the biogeochemical cycle, many are released into inland waters as industrial, mining, agricultural and domestic effluents, many of which may have deleterious effects (Dallas and Day, 2004). Chemical contamination poses a serious

\footnotetext{
*Corresponding author: Sean.Marr@ul.ac.za
}

threat to the survival of aquatic organisms. Freshwater organisms absorb contaminants from the environment (sediment and water) and their diet (Chen et al., 2000; Warren and Haack, 2001). Contaminants are incorporated into aquatic food webs and concentrated up the food chain posing a toxicity risk to the organisms that consume them: predatory fish, fish-eating birds, mammals and humans (Adams et al., 2000a). Communities who regularly consume contaminated fish are at risk to the genotoxic, carcinogenic and non-carcinogenic health impairment due to long-term exposure to toxic contaminants (du Preez et al., 2003).

In South Africa, many rural communities rely on fish harvested from local lakes, rivers and impoundments by subsistence fishers to supplement their dietary protein (Ellender et al., 2009; McCafferty et al., 2012), many illegally using gill nets (Weyl et al., 2007). However, many inland waters have become contaminated due to yearon-year increases in mining, agricultural, industrial and domestic effluent releases (Ashton and Dabrowski, 2011). The Olifants River, a tributary of the Limpopo River in South-eastern Africa, has been systemically impaired 
by acidification, industrial and agricultural chemicals, organic pollutants, and domestic waste and is now one of the most polluted river systems in South Africa (Ashton and Dabrowski, 2011). Intensive and subsistence agriculture activities, in conjunction with mining and industrial activities in the Emalahleni-Middelburg and Ba-Phalaborwa areas, significantly impact the water quality of the Olifants River (Ashton and Dabrowski, 2011), particularly in the Upper Olifants sub-catchment (Fig. 1). Acid mine drainage seeping from abandoned mines and smouldering mine dumps in the Upper Olifants River is resulting in the acidification of streams and the mobilization of metals from the sediment (McCarthy, 2011; Netshitungulwana and Yibas, 2012). Furthermore, uncontrolled release of treated and raw sewage in the Upper Olifants River (Ashton and Dabrowski, 2011) is exacerbating the situation. There is, therefore, increased concern regarding the long-term impact of water pollution on the aquatic ecosystem and the health of communities in the Olifants River catchment, especially those still reliant on untreated water or aquatic resources from the river and its impoundments (Oberholster et al., 2010).

Many studies have used fish to evaluate metal pollution in aquatic systems (Rashed, 2001) because fish are at, or near, the top of the aquatic food chain (Adams et al., 2000b). In South Africa, several studies have assessed the accumulation of metals in selected fish tissues, most of which focused on the Olifants River (Grobler et al., 1994; Seymore et al., 1995, 1996a, 1996b; Robinson and Avenant-Oldewage, 1997; Marx and Avenant-Oldewage, 1998; Nussey et al., 1999; Avenant-Oldewage and Marx, 2000a, 2000b; Coetzee et al., 2002). The potential health risks to humans consuming contaminated fish are, however, seldom addressed (Heath et al., 2004). Our study aims to assess the potential risk to human health posed by consuming Mozambique tilapia Oreochromis mossambicus (Peters, 1852) from two impoundments in the middle and lower Olifants River System, Limpopo Province, South Africa. Oreochromis mossambicus, endemic to South-eastern Africa, are a good aquaculture species as they are hardy, easy to raise and harvest, and their mild, white flesh is appealing to consumers. Oreochromis mossambicus constitutes about $4 \%$ of the total tilapia aquaculture production worldwide, has been extensively introduced for aquaculture, sport fishing, stocking manmade lakes, and biological control of nuisance plants (Froese and Pauly, 2010) and is considered one of the 100 worst invasive species (Lowe et al., 2000).

\section{Materials and methods}

\section{Study site}

Four major impoundments have been constructed on the main-stem of the Olifants River: Witbank, Loskop and Flag Boshielo dams in South Africa and Massingir Dam in Mozambique (Fig. 1). In addition, a water extraction barrage has been constructed near the border of the
Kruger National Park; the Phalaborwa Barrage (Fig. 1). This study compared the concentration of metals in the muscle tissue from $O$. mossambicus at two impoundments in the Olifants River, Limpopo province: Flag Boshielo Dam 2446 $51.46^{\prime \prime} \mathrm{S} ; 2^{\circ}{ }^{\circ} 5^{\prime} 32.57^{\prime \prime} \mathrm{E}$ (May 2009-April 2010) and Phalaborwa Barrage 24 $4^{\prime} 12^{\prime \prime} \mathrm{S}$; 31 $1^{\circ} 8^{\prime} 43^{\prime \prime} \mathrm{E}$ (April 2010-January 2011); Figure 1.

\section{Fish collection and analysis}

Oreochromis mossambicus were collected using gill nets (single net $50 \mathrm{~m}$ long, $3 \mathrm{~m}$ drop, composed of $10 \mathrm{~m}$ panels of $50-150 \mathrm{~mm}$ mesh, set overnight). Live fish were held in aerated tanks until processing. The length and weight of each fish were recorded. The fish were sacrificed by severing the spinal cord. A skinless sample of the muscle tissue $( \pm 15 \mathrm{~g})$ was collected from a subset of the fish and frozen on site. The samples were stored at $-80^{\circ} \mathrm{C}$ prior to analysis at a SANAS accredited laboratory (ISO/IEC 17025:2005) in Pretoria. The muscle tissue samples were dried, digested and analysed for metals using inductively coupled plasma - optical emission spectrometry (Perkin Elmer, Optima 2100 DV) according to the methods of Bervoets and Blust (2003). All samples were analysed in batches with blanks. Analytical accuracy was determined using certified standard from De Bruyn Spectroscopic Solutions (500MUL20-50 STD2). Recoveries were within $10 \%$ of the certified values. Box plots were plotted using R statistical software (R Development Core Team, 2014).

\section{Length-weight relationship and condition factor}

A length-weight relationship was determined for the combined data of the two impoundments using the standard power curve $W=a L^{b}$ where $W=$ body mass in grams; $L=$ standard length in $\mathrm{mm}$, and $a$ and $b$ are coefficients determined for the length-weight relationship (Anderson and Neumann, 1996). An overall condition factor index was calculated using the relative weight $\left(W r=100 \mathrm{~W} / a L^{b}\right)$ as recommended by Froese (2006). An analysis of variance (ANOVA) evaluated the differences in the condition factor index between the impoundments using the aov() function in $\mathrm{R}$.

\section{Metal bioaccumulation}

An ANOVA evaluated whether differences in metal content in the muscle tissue of $O$. mossambicus between the impoundments were significant. To evaluate differences in the multivariate metal concentrations of $O$. mossambicus between the two impoundments, a resemblance matrix was constructed using Euclidean distance and a nonmetric multi-dimensional scaling (NMDS) plot prepared to visualize the results using the metaMDS() function in the VEGAN package for R (Oksanen et al., 2013). 


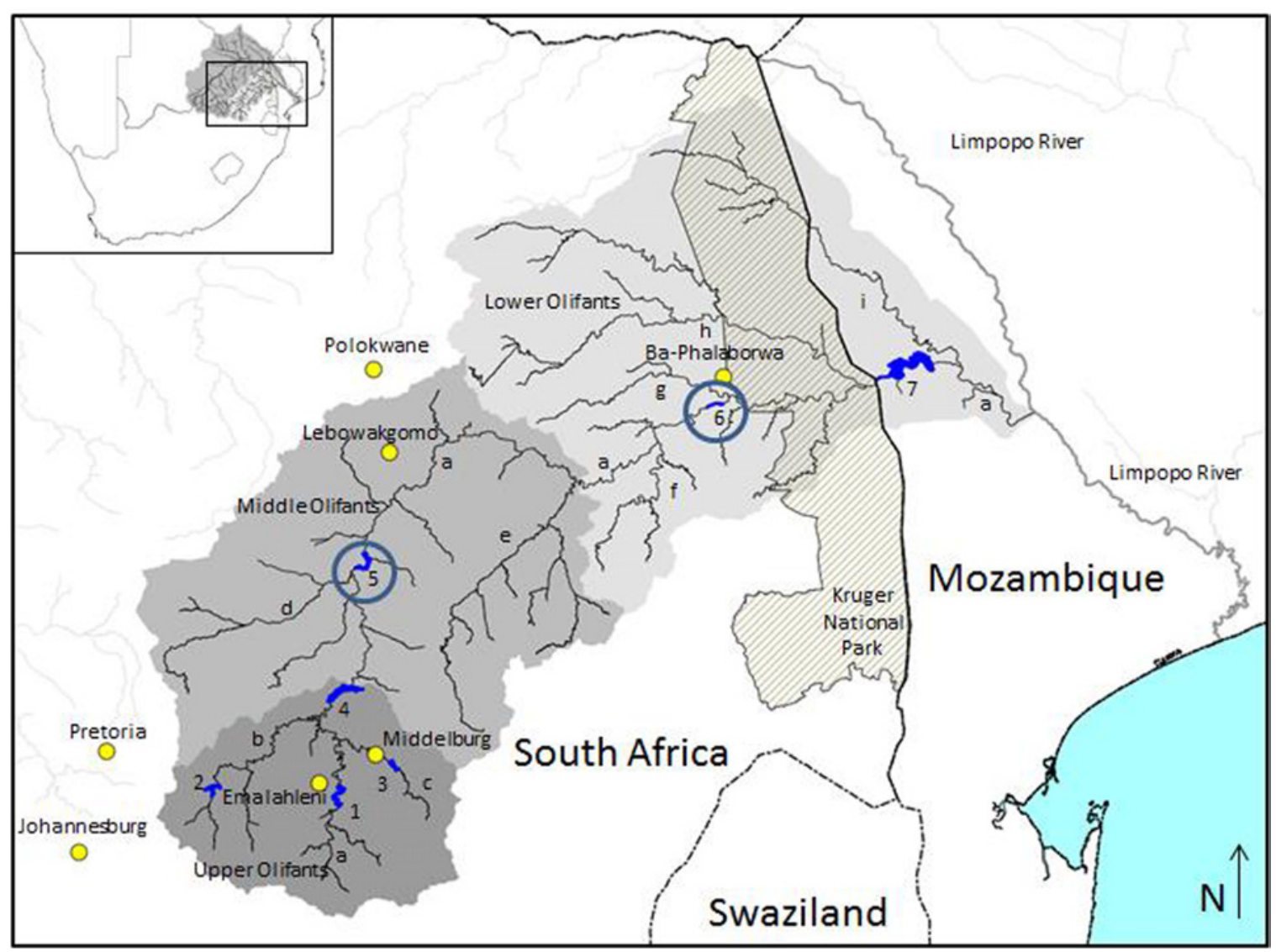

Fig. 1. Map of the Olifants River system showing the location of major towns, impoundments and tributaries. Major impoundments are depicted by numbers: (1) Witbank Dam, (2) Bronkhorstspruit Dam, (3) Middelburg Dam, (4) Loskop Dam, (5) Flag Boshielo Dam, (6) Phalaborwa Barrage and (7) Massingir Dam. The Olifants River and its tributaries are depicted by letters: (a) Olifants mainstem, (b) Wilge, (c) Klein Olifants, (d) Elands, (e) Steelpoort, (f) Blyde, (g) Ga-Selati, (h) Letaba and (i) Shingwedzi. The study sites, Flag Boshielo Dam and the Phalaborwa Barrage, are circled.

The metal concentrations were fourth root transformed to reduce the confounding effect of metals that were present in high concentrations (e.g., iron and aluminium).

A distance-based test of homogenity of multivariate dispersion and a multivarite analysis of variance tests (Anderson, 2001a, 2001b; McCafferty et al., 2012) were performed to determine whether there was a statistically significant difference in the muscle metal concentrations of $O$. mossambicus populations from the two impoundments using the betadisper() and MRPP() functions in VEGAN. The betadisper() routine (Dispersion) determined whether the multivariate dispersion about the group centroid differed between the populations, whereas the MRPP routine (MANOVA) determined whether the position of the group centroids in multivariate space and/or multivariate dispersion about the group centroid differed between the populations (Anderson, 2001a, 2001b).

A SIMPER analysis was performed to determine the main metals contributing to the differences between $O$. mossambicus from the two impoundments using the simper() function in VEGAN. The Kendall tau-B correlation coefficient was calculated for each impoundment to determine whether there was any correlation between the respective metals in the muscle tissue using the corr() function in R.

\section{Human health risk assessment}

A human health risk assessment was carried out using the methodology of the US Environmental Protection Agency (US-EPA, 2000) as revised for South Africa by Heath et al. (2004). The risk of chronic non-cancer health effects from oral exposure was calculated using the average daily dose (ADD) and expressed in $\mathrm{mg} \mathrm{kg}^{-1}$ body mass per day:

$$
\mathrm{ADD}=\frac{\left(\begin{array}{c}
\text { average metal concentration in fish muscle }(\mathrm{fw})) \times \\
\text { (mass of portion) }
\end{array}\right.}{\left(\begin{array}{c}
\text { (adult body mass) } \times \\
\text { (no. of days between fish meals) }
\end{array}\right.}
$$

where the average metal concentration is in $\mathrm{mg} \mathrm{kg}^{-1}$, mass of portion in $\mathrm{kg}$, adult body mass in $\mathrm{kg}$ and no. of days between fish meals in days.

Risk assessments evaluating non-carcinogenic toxic effects of contaminants use reference doses (RfDs) as 


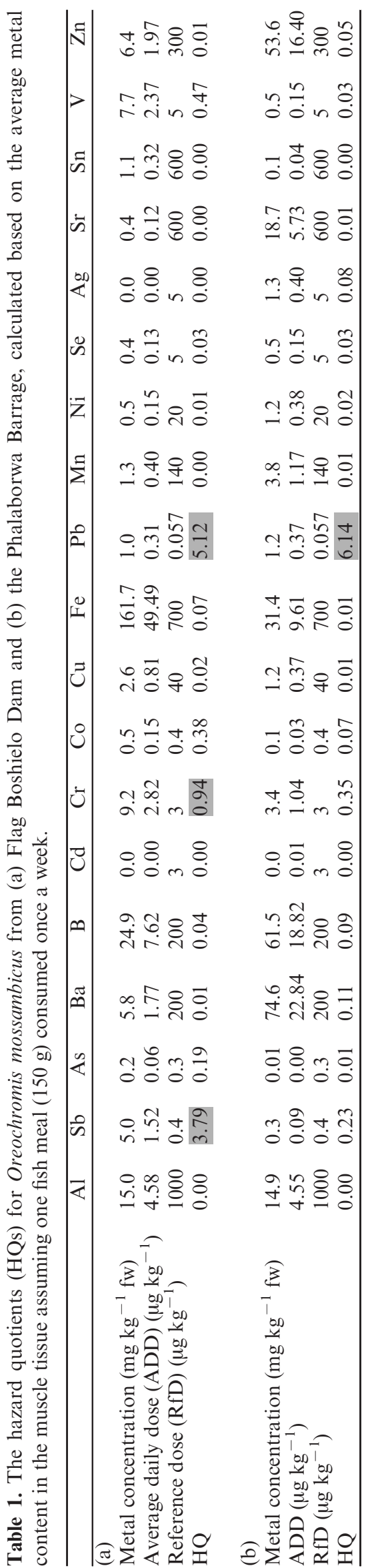

thresholds above which adverse health impacts could be expected. A hazard quotient (HQ) was calculated to estimate the risk to human health:

$$
\mathrm{HQ}=\frac{\mathrm{ADD}}{\mathrm{RfD}}
$$

where $\mathrm{HQ}<1$ suggests adverse health effects are unlikely and $\mathrm{HQ}>1$ suggests a high probability of adverse health effects. In order to calculate the ADD, a number of assumptions are required to characterise the population at risk: $150 \mathrm{~g}$ portion once a week; $70 \mathrm{~kg}$ adult; and 30-year exposure (not used in the calculation, but the basis of the risk assessment). The average metal concentration in the muscle tissues from each impoundment was used in the health risk assessment (Table 1). RfD levels published by the US-EPA were used (US-EPA, 2012).

\section{Results}

\section{Length-weight relationship and relative weight}

The length-weight relationship developed for $O$. mossambicus from the two impoundments was Weight $=$ $1.568 \times 10^{-5} * \mathrm{~L}^{3.126}\left(n=85\right.$; adjusted $\left.R^{2}=0.944\right)$. The $O$. mossambicus from the Phalaborwa Barrage were significantly smaller than those from Flag Boshielo Dam (ANOVA $P<<0.001$ ). Oreochromis mossambicus was found to have positive allometric growth $(b>3.0)$. The relative weight for $O$. mossambicus was significantly different between the two impoundments (ANOVA $P=0.043$ ) as a result of the smaller individuals from the Phalaborwa Barrage. We found no clear relationship between relative weight and standard length for either impoundment (ANOVA $P>0.74$ ).

\section{Metals in muscle tissue}

The metal concentration in the O. mossambicus muscle from Flag Boshielo Dam were significantly higher than those from the Phalaborwa Barrage for arsenic, chromium, iron, tin and vanadium whereas barium, boron, cadmium, manganese, silver, strontium and zinc were significantly higher in fish from the Phalaborwa Barrage (ANOVA $P<0.05$; Fig. 2). The NMDS plot of the metal concentrations in muscle tissues shows a clear separation between specimens from the two impoundments (Fig. 3). The Dispersion result was not significant $(P=0.5)$, whereas the MANOVA result was significant $(P<0.001)$ indicating that there was a statistically significant difference between the impoundments.

The SIMPER analysis showed that about $75 \%$ of the dissimilarity between the metal concentrations in muscle tissues of $O$. mossambicus from the two impoundments can be attributed to barium, strontium, vanadium, iron, zinc, silver and antimony. About $80 \%$ of the similarity within the Flag Boshielo Dam population can be attributed to iron, antimony, cobalt, tin and selenium, whereas about $88 \%$ of the similarity within the Phalaborwa Barrage 

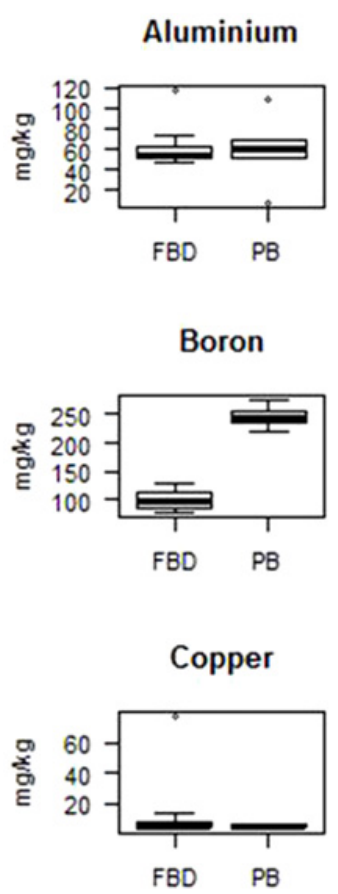

Nickel

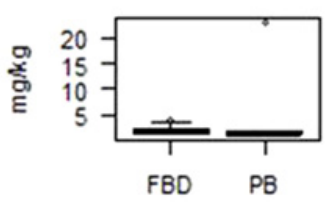

Tin

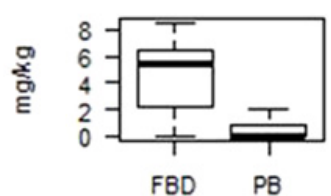

Antimony

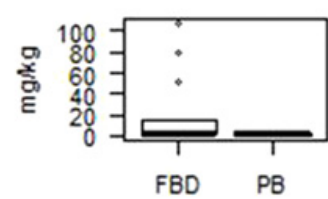

Cadmium

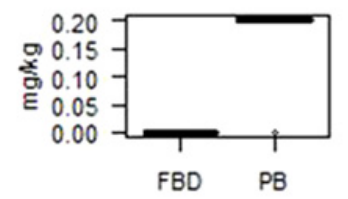

Iron

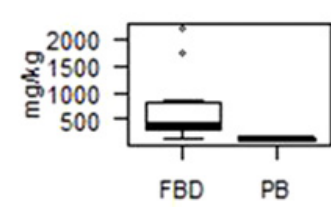

Selenium

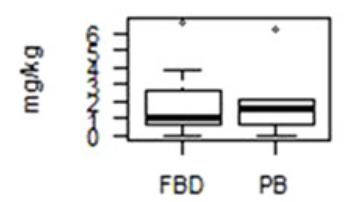

Titanium

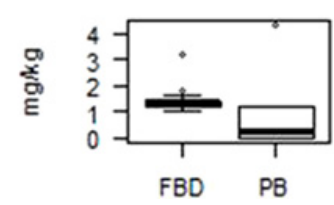

Arsenic

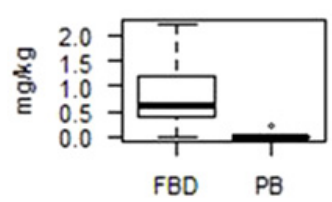

Chromium

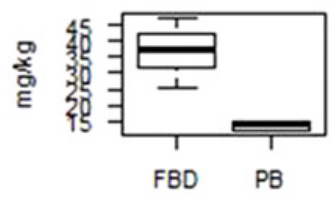

Lead

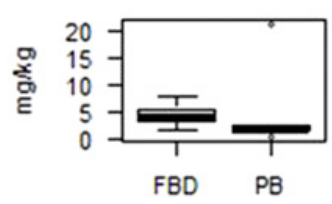

Silver

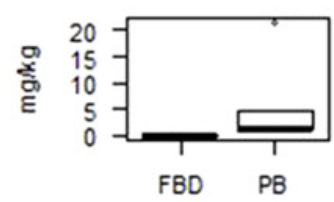

Vanadium

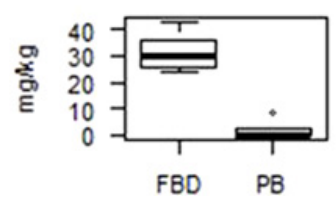

Barium

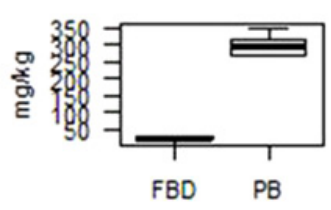

Cobalt

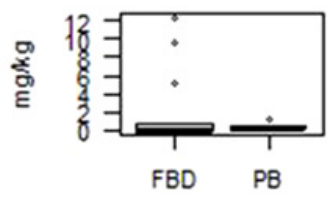

Manganese

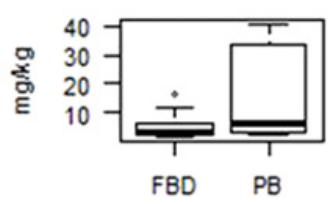

Strontium
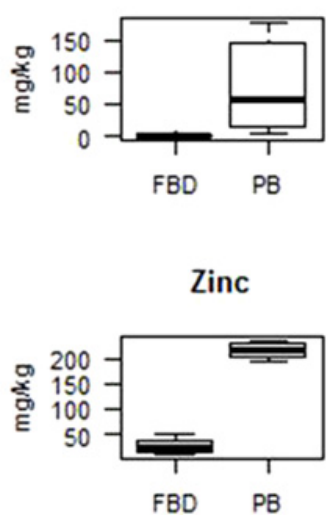

Fig. 2. Box and whisker plots of metal concentrations ( $\mathrm{mg} \mathrm{kg}^{-1}$ dry weight), in the muscle tissue of Oreochromis mossambicus from Flag Boshielo Dam and Phalaborwa Barrage.

population can be attributed to strontium, vanadium, titanium, antimony, tin, manganese, aluminium and selenium.

\section{Inter-metal relationship}

Correlations of metals within O. mossambicus muscle samples from both impoundments are presented in Table S1 (online material available at: www.limnologyjournal.org). The concentrations of metals and metalloids in the fish were quite variable and no patterns were noted. At Flag Boshielo Dam, Fe was strongly correlated with $\mathrm{Mn}, \mathrm{Sb}$ with $\mathrm{Ni}$ and $\mathrm{Pb}$, and $\mathrm{Zn}$ with $\mathrm{V}$, whereas at the Phalaborwa Barrage $\mathrm{Co}, \mathrm{Mn}$ and $\mathrm{Sr}$ were strongly correlated with $\mathrm{V}, \mathrm{Cr}$ and $\mathrm{Sb}$ with $\mathrm{Ti}, \mathrm{Pb}$ with $\mathrm{Zn}$, Se with $\mathrm{Cu}$, and $\mathrm{Cd}$ and $\mathrm{Mn}$ with $\mathrm{Co}$.

\section{Human health risk assessment}

The total HQs of O. mossambicus from Flag Boshielo Dam was 1.5 times greater than that for the Phalaborwa Barrage (Table 1). The recommended HQ of 1 was exceeded for antimony, chromium $(\mathrm{HQ}=0.94)$ and lead at Flag Boshielo Dam and for lead at the Phalaborwa Barrage (Table 1). For Flag Boshielo Dam, the contributions of the metals to the HQ value were $\mathrm{Pb}>\mathrm{Sb}>>$ $\mathrm{Cr}>\mathrm{V}>\mathrm{Co}>\mathrm{As}$, whereas for the Phalaborwa Barrage, the contributions were $\mathrm{Pb}>>\mathrm{Cr}>\mathrm{Sb}>\mathrm{Ba}$.

\section{Discussion}

The metal concentration in the muscle tissue appears to be increasing at both impoundments, in particular the 


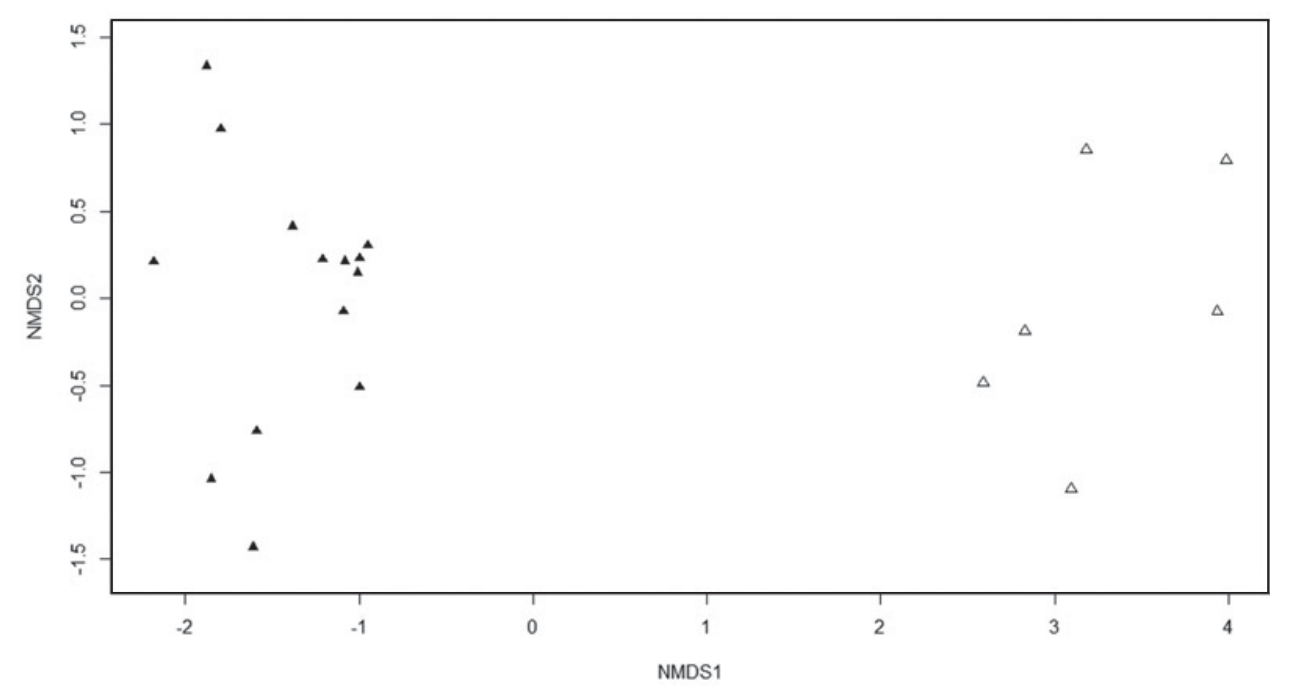

Fig. 3. Non-metric multi-dimensional scaling plot for the metal concentration in the muscle tissue of Oreochromis mossambicus from the Flag Boshielo Dam and the Phalaborwa Barrage based on Euclidean distance and a fourth root transform. The data points for the Flag Boshielo Dam are represented by solid symbols whereas those for the Phalaborwa Barrage are represented by open symbols.

concentrations of aluminium, chromium, copper and iron; however, the relative weight indicates that both populations appear to be in good health. These results confirm that the deteriorating water quality identified in other studies, e.g., de Villiers and Mkwelo (2009) and Ashton and Dabrowski (2011), is beginning to have knock-on impacts on the aquatic biota and rural communities in the catchment. Acid mine drainage, prevalent in the upper catchment (Ashton and Dabrowski, 2011; McCarthy, 2011), is mobilising metals from the sediment and bedrock in the Olifants River (McCarthy, 2011; Netshitungulwana and Yibas, 2012). These metals are absorbed by fish through their diet or from their environment (sediment and water), accumulating in their bodies, and potentially exerting toxic impacts on organisms consuming the fish (McCarthy and Shugart, 1990; Marzouk, 1994). The differences in metals accumulated by O. mossambicus at the two impoundments could be attributed to differences in metal concentrations in the water and sediment at the two localities; however, no support for such a relationship was found at these sites (Jooste et al., 2014).

Two studies investigated metal bioaccumulation of eight metals in O. mossambicus from the Olifants River (Table 2). The Phalaborwa Barrage, Loskop Dam above Flag Boshielo Dam and Mamba weir in the Kruger National Park were included in one study (Kotzè, 1997; Kotzè et al., 1999). The second study focused on Kruger National Park sites: Mamba Weir and Balule (Robinson, 1996; Robinson and Avenant-Oldewage, 1997). Flag Boshielo Dam was not included in either study, although Loskop Dam could be used for comparison. The values for aluminium, chromium, copper and iron were higher at Flag Boshielo Dam (current study) than those for Loskop Dam 20 years ago, whereas the values for lead, manganese, nickel and zinc were lower. For the Phalaborwa
Barrage, all metals were higher than 20 years ago. In fact, aluminium, copper, manganese and zinc were currently higher at Phalaborwa Barrage than at Loskop Dam 20 years ago. Comparing the Phalaborwa Barrage to the downstream sites (Mamba Weir and Balule), the current results for aluminium and zinc were higher at the barrage than at both downstream sites, whereas copper was higher than at Balule. The historical metal pollution at the Kruger National Park sites could be attributed to the Phalaborwa Mineral Complex releasing water from tailings dam into the Selati River, a tributary whose confluence with the Olifants River is below the Phalaborwa Barrage. These tailings dam releases were prohibited in 2002, although spills continue to occur following large rainfall events.

The lead, antimony, arsenic and chromium concentrations in the muscle tissue were comparable to results from other studies of metal accumulation in $O$. mossambicus and other Oreochromis species (Al-Kahtani, 2009; Yilmaz, 2009; Jabeen and Chaudhry, 2010). A study in the Pearl River estuary, China, found that $\mathrm{As}$ and $\mathrm{Pb}$ can accumulate to exceptionally high concentrations in $O$. mossambicus muscle tissue with average $\mathrm{As}$ and $\mathrm{Pb}$ concentrations ranging between 0.42 and 2.24 , and 0.05 and $7.74 \mathrm{mg} \mathrm{kg}^{-1}$ (fw) at five ponds, respectively (Cheung et al., 2008). The levels of chromium found in $O$. mossambicus muscle from the Pearl River estuary were lower than our results ranging between 0.10 and $2.42 \mathrm{mg} \mathrm{kg}^{-1} \mathrm{fw}$ at the five ponds (Cheung et al., 2008). We could not find any studies that reported antimony concentrations in Oreochromis sp.

Correlations between the concentration of the respective metals in fish tissues may result from the similar accumulation pathways in fish (Rejomon et al., 2010); however, the extent of metal uptake from contaminated water bodies may vary according to ecological and 
physiological needs, in conjunction with environmental parameters (Pagenkopf, 1983). No patterns in the correlation between metal pairs in the muscle tissue of $O$. mossambicus were observed for the two impoundments. However, Jooste et al. (2014) found strong correlation coefficients between the patterns of metal accumulation in $O$. mossambicus and three other species (Labeo rosae (Steindachner, 1894), Clarias gariepinus (Burchell, 1822) and Schilbe intermedius (Rüppell, 1832)) within each impoundment (Spearman $\rho>0.8$ for all pairs excluding $S$. intermedius; $\rho>0.6$ for all pairs including $S$. intermedius). The difference between $S$. intermedius and the other species could be explained by differences in the pelagic and demersal food webs. $S$. intermedius is predominantly a pelagic predator assimilating metals from the water column and pelagic food, whereas the other species are demersal (Skelton, 2001) and more likely to assimilate metals from the sediment and benthic food.

\section{Human health risk assessment}

Many rural communities in the Olifants River catchment rely on fish from the river and its impoundments as a dietary protein supplement. The bioaccumulation results confirm that $O$. mossambicus are assimilating metals in their muscle tissue. The human health risk assessment revealed that certain metals, viz. lead, antimony and chromium, in O. mossambicus muscle tissue exceed acceptable levels for safe consumption such that an adult consuming a $150 \mathrm{~g}$ portion once a week may be exposing themselves to serious health risks. The risk associated with consuming fish from Flag Boshielo Dam is 50\% greater than that for the Phalaborwa Barrage.

If the trend of increasing metal pollution levels in the Olifants River continues, it is predicted that the risks to human health posed by the consumption of contaminated fish would increase and additional metals would exceed acceptable levels for the safe consumption of $O$. mossambicus; e.g., vanadium, cobalt and arsenic. Considering that the rural populations will continue to increase and that poverty will increasingly necessitate the supplementing of dietary protein, an increase in the frequency of consumption of fish from the impoundments is probable. This is of great concern because $O$. mossambicus, with sharptooth catfish $C$. gariepinus, are the favoured fish among the rural communities and are targeted more intensely by subsistence fishers.

Subsistence fishers are the main source of fish to rural communities, but they were historically excluded from utilizing impoundments (Weyl et al., 2007; McCafferty et al., 2012). Due to limited resources, local conservation authorities no longer patrol impoundments resulting in increased illegal use of gill nets by subsistence fishers. The indiscriminate use of gill nets, unsustainable fishing pressure (McCafferty et al., 2012), and pollution are contributing to the decline of fish stocks in the Olifants River impoundments, raising concern regarding the conservation of endemic species. However, subsistence fishing 
provides an income source and fish to the community and is becoming an important sector in rural livelihood (McCafferty et al., 2012). The South African government has proposed the establishment of fisheries in impoundments, many of which would intentionally target introduced species in the Western and Eastern Cape. Currently inland fisheries are poorly developed and previous attempts to establish inland fisheries have failed (Weyl et al., 2007; McCafferty et al., 2012). Weyl et al. (2007) identified four types of fisheries: open access equilibrium, community-managed subsistence, commercial and recreational. To supply fish to rural communities, the community-managed subsistence fishery is the most likely to succeed provided it is founded on the principles of biological sustainability and optimum economic benefits (Weyl et al., 2007) and has the support of local community leaders. However, our results indicate that fish from the impoundments of the Olifants River should not be considered as a basis for fishery development because they may pose an unacceptable health risks and the pollution trends in the basin indicate that these health risks will increase in the future. The metal pollution in the Olifants River system, driven by acid mine drainage in the upper catchment, needs to be addressed before fishery development in the Olifants River impoundments can be considered. However, the current unregulated subsistence fisheries are likely to continue unabated posing a health risk to the rural communities and an extirpation risk to fish stocks in the impoundments.

Acknowledgements. The authors acknowledge the Water Research Commission, South Africa (WRC) and Vlaamse Interuniversitaire Raad - University Development Cooperation (VLIR-IUC) Funding Programme (Belgium) for funding this research and members of the WRC project steering committee for their assistance, constructive discussions and inputs during the project. We also thank our UL colleagues: Dr Moses Matla, Mr Willem Smit, Mr Hendrik Hattingh and our postgraduate students for their valuable time and input during the field surveys and laboratory work.

\section{References}

Adams W.J., Conrad B., Ether G., Brix K.V., Paquim P.R. and di Toro D., 2000a. The challenges of hazard identification and classification of insoluble metals and metal substances for the aquatic environment. Hum. Ecol. Risk Assess., 6, 1019-1038.

Adams W.J., Toll J.E., Brix K.V., Tear L.M. and DeForest D.K., 2000b. Site-specific approach for setting water quality criteria for selenium: differences between lotic and lentic systems. In: Rosentreter R. and Bittman K. (eds.), Proceedings of the 24th Annual British Columbia Mine Reclamation Symposium, Williams Lake, BC, 232-236.

Al-Kahtani M.A., 2009. Accumulation of heavy metals in tilapia fish (Oreochromis niloticus) from Al-Khadoud Spring, Al-Hassa, Saudi Arabia. Am. J. Appl. Sci., 6, 2024-2029.

Anderson M.J., 2001a. A new method for non-parametric multivariate analysis of variance. Aust. Ecol., 26, 32-46.
Anderson M.J., 2001b. Permutation tests for univariate or multivariate analysis of variance and regression. Can. J. Fish Aquat. Sci., 58, 626-639.

Anderson R.O. and Neumann R.M., 1996. Length, weight, and associated structural indices. In: Murphy B.R. and Willis D.W. (eds.). Fisheries Techniques. American Fisheries, Bethesda, MD.

Ashton P.J. and Dabrowski J.M., 2011. An overview of water quality and the causes of poor water quality in the Olifants River Catchment. WRC Project No. K8/887. Water Research Commission, Pretoria. 189 p.

Avenant-Oldewage A. and Marx H.M., 2000a. Bioaccumulation of chromium, copper and iron in the organs and tissues of Clarias gariepinus in the Olifants River, Kruger National Park. Water SA, 26, 569-582.

Avenant-Oldewage A. and Marx H.M., 2000b. Manganese, nickel and strontium bioaccumulation in the organs and tissues of the African sharptooth catfish, Clarias gariepinus from the Olifants River, Kruger National Park. Koedoe, 43, 17-33.

Bervoets L. and Blust R., 2003. Metal concentrations in water, sediment and gudgeon (Gobio gobio) from a pollution gradient: relationship with fish condition factor. Environ. Pollut., 26, 9-19.

Beveridge M.C.M., Thilsted S.H., Phillips M.J., Metian M., Troell M. and Hall S.J., 2013. Meeting the food and nutrition needs of the poor: the role of fish and the opportunities and challenges emerging from the rise of aquaculturea. J. Fish Biol., 83, 1067-1084.

Chen C.Y., Stemberger R.S., Klaue B., Blum J.D., Pickhardt P.C. and Folt C.L., 2000. Accumulation of heavy metals in food web components across a gradient of lakes. Limnol. Oceanogr., 45, 1525-1536.

Cheung K.C., Leung H.M. and Wong M.H., 2008. Metal concentrations of common freshwater and marine fish from the Pearl River Delta, South China. Arch. Environ. Contam. Toxicol., 54, 705-715.

Coetzee L., du Preez H.H. and van Vuren J.H.J., 2002. Metal concentrations in Clarias gariepinus and Labeo umbratus from the Olifants and Klein Olifants River, Mpumalanga, South Africa: zinc, copper, manganese, lead, chromium, nickel, aluminium and iron. Water $S A, 28$, 433-448.

Dallas H.F. and Day J.A., 2004. The effect of water quality variables on aquatic ecosystems: a review. WRC Report No. TT224/04. Water Research Commission, Pretoria, South Africa, $222 \mathrm{p}$.

de Villiers S. and Mkwelo S.T., 2009. Has the monitoring failed the Olifants River, Mpumalanga? Water SA, 35, 671-676.

du Preez H.H., Heath R.G.M., Sandham L.A. and Genthe B., 2003. Methodology for the assessment of human health risks associated with the consumption of chemical contaminated freshwater fish in South Africa. Water SA, 29, 69-90.

Ellender B.R., Weyl O.L.F. and Winker H., 2009. Who uses the fishery resources in South Africa's largest impoundment? Characterising subsistence and recreational fishing sectors on Lake Gariep. Water SA, 35, 677-682.

Froese R., 2006. Cube law, condition factor and weight-length relationships: history, meta-analysis and recommendations. J. Appl. Ichthyol., 22, 241-253.

Froese R. and Pauly D. (eds.), 2010. FishBase 2010: Concepts, Design and Data Sources, International Center for Living 
Aquatic Resource Management, Manila. Available online at: www.fishbase.org

Grobler D.F., Kempster P.L. and van der Merwe L., 1994. A note on the occurrence of metals in the Olifants River, Eastern Transvaal, South Africa. Water SA, 20, 195-204.

Heath R.G.M., du Preez H.H., Genthe B. and AvenantOldewage A., 2004. Freshwater fish and human health. Reference guide. WRC Report No.TT212/04. Water Research Commission, Pretoria, South Africa. xii + 135 p.

Jabeen F. and Chaudhry A., 2010. Environmental impacts of anthropogenic activities on the mineral uptake in Oreochromis mossambicus from Indus River in Pakistan. Environ. Monit. Assess., 166, 641-651.

Jooste A., Luus-Powell W.J. and Addo-Bediako A., 2014. The impact of water and sediment quality on the health of fish and the diversity of fish parasites in two impoundments of the Olifants River, Limpopo province. WRC Project No. K5/1929. Water Research Commission, Pretoria, 189 p.

Kotzè P.J., 1997. Aspects of water quality, metal contamination of sediment and fish in the Olifants River, Mpumalanga. MSc in Zoology, Faculty of Natural Sciences, University of Johannesburg, Johannesburg, 361 p.

Kotzè P.J., du Preez H.H. and van Vuren J.H.J., 1999. Bioaccumulation of copper and zinc in Oreochromis mossambicus and Clarias gariepinus, from the Olifants River, Mpumalanga, South Africa. Water SA, 25, 99-110.

Lowe S., Browne M., Boudjelas S. and De Poorter M., 2000. 100 of the World's Worst Invasive Alien Species: a selection from the Global Invasive Species Database, Invasive Species Specialist Group, Auckland, New Zealand, 12 p.

Marx H.M. and Avenant-Oldewage A., 1998. A further investigation into the bioaccumulation of lead and zinc in the organs and tissues of the African sharptooth catfish, Clarias gariepinus from two localities in the Olifants River, Kruger National Park. Koedoe, 41, 27-43.

Marzouk M., 1994. Fish and environment pollution. Vet. Med. J., 42, 51-52.

McCafferty J.R., Ellender B.R., Weyl O.L.F. and Britz P.J., 2012. The use of water resources for inland fisheries in South Africa: review. Water $S A, 38,327-343$.

McCarthy J.F. and Shugart L.R., 1990. Biomarkers of Environmental Contamination, Lewis Publishers, New York, 475 p.

McCarthy T.S., 2011. The impact of acid mine drainage in South Africa. S. Afr. J. Sci., 107, 1-7.

Netshitungulwana R. and Yibas B., 2012. Stream sediment geochemistry of the Olifants catchment, South Africa: Implication for acid mine drainage. In: McCullough C.D., Lund M.A. and Wyse L. (eds.), Proceedings of the International Mine Water Association Symposium, International Mine Water Association, 257-264.

Nussey G., van Vuren J.H.J. and du Preez H.H., 1999. Bioaccumulation of aluminium, copper and zinc in the tissues of moggel from Witbank Dam, Upper Olifants River Catchment (Mpumalanga). S. Afr. J. Wildl. Res., 29, 130-144.

Oberholster P.J., Myburgh J.G., Ashton P.J. and Botha A.-M., 2010. Responses of phytoplankton upon exposure to a mixture of acid mine drainage and high levels of nutrient pollution in Lake Loskop, South Africa. Ecotox. Environ. Safe, 73, 326-335.
Oksanen J., Blanchet F.G., Kindt R., Legendre P., O’Hara R.B., Simpson G.L., Solymos P., Stevens M.H.H. and Wagner H., 2013. VEGAN: Community Ecology Package version 2.0-9. Available online at: http://R-Forge.R-project.org/projects/ vegan/, $78 \mathrm{p}$.

Pagenkopf G.K., 1983. Gill surface interaction model for tracemetal toxicity to fishes: role of complexation, $\mathrm{pH}$, and water hardness. Environ. Sci. Technol., 17, 342-347.

Rashed M., 2001. Cadmium and lead levels in fish (Tilapia nilotica) tissues as biological indicator for lake water pollution. Environ. Monit. Assess, 68, 75-89.

R Development Core Team, 2014. R: A Language and Environment for Statistical Computing. R Foundation for Statistical Computing, Vienna, Austria, Available online at: http://www.R-project.org.

Rejomon G., Nair M. and Joseph T., 2010. Trace metal dynamics in fishes from the southwest coast of India. Environ. Monit. Assess., 167, 243-255.

Robinson J., 1996. Evaluation of the Health Assessment Index with reference to bioaccumulation of metals in Oreochromis mossambicus (Peters, 1852) and aspects of the morphology of Lernaea cyprinacea Linnaeus 1758. MSc Dissertation, Rand Afrikaans University, Johannesburg.

Robinson J. and Avenant-Oldewage A., 1997. Chromium, copper, iron and manganese bioaccumulation in some organs and tissues of Oreochromis mossambicus from the lower Olifants River, inside the Kruger National Park. Water SA, 23, 387-404.

Sayer J. and Cassman K.G., 2013. Agricultural innovation to protect the environment. Proc. Natl. Acad. Sci. USA, 110, 8345-8348.

Seymore T., du Preez H.H. and van Vuren J.H.J., 1995. Manganese, lead and strontium bioaccumulation in the tissues of the yellowfish, Barbus marequensis from the lower Olifants River, Eastern Transvaal. Water SA, 21, $159-172$.

Seymore T., du Preez H.H. and van Vuren J.H.J., 1996 . Concentration of zinc in Barbus marequensis from the lower Olifants River, Mpumalanga, South Africa. Hydrobiologia, 332, 141-150.

Seymore T., du Preez H.H. and van Vuren J.H.J., 1996 b. Concentrations of chromium and nickel in Barbus marequensis from the lower Olifants River Mpumalanga, South Africa. S. Afr. J. Zool., 31, 101-109.

Skelton P.H., 2001. A Complete Guide to the Freshwater Fishes of Southern Africa, Struik Publishers, Cape Town, South Africa, $395 \mathrm{p}$.

US-EPA, 2000. Guidance for Assessing Chemical Contaminant Data for use in Fish Advisories. Volume 2: Risk Assessment and Fish Consumption Limits, 3rd edn, EPA 823-B-00-008. Office of Health and Environmental Assessment, Washington, DC, $383 \mathrm{p}$.

US-EPA, 2012. Regional Screening Table: Composite Table May 2012. In: United States Environmental Protection Agency, Mid-Atlantic Risk Assessment, Available online at: http://water.epa.gov/scitech/swguidance/standards/criteria/ current/index.cfm, Accessed online September 2012.

Vörösmarty C.J., McIntyre P.B., Gessner M.O., Dudgeon D., Prusevich A., Green P., Glidden S., Bunn S.E., Sullivan C.A. and Liermann C.R., 2010. Global threats to human water security and river biodiversity. Nature, 467, 555-561. 
Warren L.A. and Haack E.A., 2001. Biogeochemical controls on metal behaviour in freshwater environments. Earth-Sci. Rev., 54, 261-320.

Weyl O.L.F., Potts W.M. and Rouhani Q., 2007. The need for an inland fisheries policy in South Africa: a case study of the North West Province. Water SA, 33, 497-504.
Yilmaz F., 2009. The comparison of heavy metal concentrations $(\mathrm{Cd}, \mathrm{Cu}, \mathrm{Mn}, \mathrm{Pb}$, and $\mathrm{Zn})$ in tissues of three economically important fish (Anguilla anguilla, Mugil cephalus and Oreochromis niloticus) inhabiting Koycegiz Lake-Mugla (Turkey). Turk. J. Sci. Tech., 4, $7-15$. 